\title{
So You Think You Can Dance? Lessons from the U.S. Private Equity Bubble
}

\author{
Catherine J. Turco, Ezra W. Zuckerman
}

Massachusetts Institute of Technology

\begin{abstract}
This article develops a sociologically informed approach to market bubbles by integrating insights from financial-economic theory with the concepts of voice and dissimulation from other cases of distorted valuation studied by sociologists (e.g., witch hunts, unpopular norms, and support for authoritarian regimes). It draws on unique datalongitudinal interviews with private equity market participants during and after that market's mid-2000s bubble-to test key implications of two existing theories of bubbles and to move beyond both. In doing so, the article suggests a crucial revision to the behavioral finance agenda, wherein bubbles may pertain less to the cognitive errors individuals make when estimating asset values and more to the sociological and institutionally driven challenge of how to interpret complex social and competitive environments.
\end{abstract}

Keywords: financial markets; bubbles; valuation; private equity

Editor(s): Jesper Sørensen, Olav Sorenson; Received: September 16, 2013; Accepted: October 27, 2013; Published: March 24, 2014

Citation: Turco, Catherine J., and Ezra W. Zuckerman. 2014. "So You Think You Can Dance? Lessons from the U.S. Private Equity Bubble." Sociological Science 1: 81-101. D0I: 10.15195/v1.a7

Copyright: (C) 2014 Turco and Zuckerman. This open-access article has been published and distributed under a Creative Commons Attribution License, which allows unrestricted use, distribution and reproduction, in any form, as long as the original author and source have been credited.

vexing question for both social scientists and A policy makers is why public valuations (the majority's publicly enacted preferences) often become wildly disjointed from objective conditions. Well-known examples include moral panics like witch hunts, in which fantastical beliefs are widely endorsed; the cult of personality in authoritarian regimes, where millions of people proclaim allegiance to a cruel leader or bankrupt ideology; norms that are broadly enforced despite questionable social value; and financial market bubbles, when prices greatly exceed valuations justified by the economic fundamentals.

A common account of such episodes is that people have succumbed to mass hysteria or delusion. However, sociological and political science studies highlight mechanisms of exit and voice (Hirschman 1970). That is, support for authoritarian regimes often depends less on citizens' delusion about how the regime governs and more on restrictions on speech and assembly that silence their dissent, and on social pressure that motivates them to dissimulate (publicly feign allegiance) (Wedeen 1999). Similar logic holds in less extreme cases like moral panics and questionable norms (Centola, Willer, and Macy 2005). There, actors may be highly committed to a par- ticular community, thus limiting their use of exit, and voicing dissent may be socially risky, even if formally permissible.

From this perspective, though, financial market bubbles are hard to explain. After all, financial markets are defined by vehicles for exit and voice, with such vehicles eliminating distortions in prevailing public valuations (prices). Consider the stock market. If investors believe stocks are overpriced, they can exit by selling their shares, thus lowering prices. Also, investors can publicly question the inflated prices with no attendant social risk, both informally and through various forms of arbitrage. Because such arbitrage generates high returns when skeptical investors are right, significant gaps between price and value should never endure. Accordingly, the orthodox financial-economic view of bubbles - as summarized in the efficient market hypothesis (EMH)argues that the mechanisms supporting exit and voice in markets are so powerful, and the incentives for using them so high, that bubbles are effectively impossible (Garber 2000).

Yet bubbles do occur. Examples include Dutch tulips in the 1630s, shares of the South Sea Company in 1720, the U.S. stock market of the 1920s, Internet stocks in the late 1990s, U.S. housing 
in the 2000s, and the subject of this articlethe mid-2000s U.S. private equity bubble, when asset prices rose far above historic levels. Echoing accounts of other distorted public valuations, heterodox scholars have adopted one of two approaches when explaining these phenomena.

\section{Collective Delusion}

The most prominent heterodox approach assumes that bubbles inflate when a majority of investors become collectively deluded about asset values ${ }^{1}$ By some accounts, investors are driven to unreasonable estimates of value when they convince themselves that "this time is different"that inflated prices make sense because of fundamental economic changes invalidating "the old rules of financial valuation" (Reinhart and Rogoff 2009:xxxiv). Some argue that inflated valuations are especially likely when investors can obtain capital (in particular credit) cheaply because investors often ignore the cost of financing when estimating asset values (Minsky 1975, 1992). In general, behavioral economists focus on cognitive biases that lead investors to make mathematical errors or factual mistakes when estimating asset values (Lamont and Thaler 2003; Rashes 2001), whereas sociologists emphasize investors' reliance on flawed theories of value that render them oblivious to major mispricings (MacKenzie 2011; Zuckerman and Rao 2004). Yet whether ascribed to "animal spirits" (Akerlof and Shiller 2009), "euphoria" (Kindelberger [1978] 2005:13), a "fieldwide delusion" (Fligstein and Goldstein 2010:34), or a "miasma of irrationality" (Pozner, Stimmler, and Hirsch 2010:5), all such accounts suggest that bubbles are driven by widespread delusion about asset values.

\section{Institutionalist Perspective}

In contrast, a second approach suggests that bubbles can form without widespread delusion. Investors may recognize a mispricing, but institutional conditions prevent them from voicing dissent and correcting the distortion. Two variants of this perspective propose two distinct strate-

\footnotetext{
${ }^{1}$ By "majority of investors," we mean the majority of capital in the market.
}

gies that dissenting investors adopt and that fuel bubbles.

\section{Silenced Voice through Rational Sitting}

During a bubble, short selling is the key way skeptical investors can dissent from prevailing public valuations and correct market distortions. It is the market equivalent of standing in the common square and proclaiming that the authoritarian regime is bankrupt or the witch hunt overblown. Specifically, it involves an investor borrowing a security the investor thinks is overpriced and selling it at that inflated price, then buying it back later after the price has fallen to repay the original owner and keep the profit. When orthodox theory assumes that bubbles are impossible because price-value distortions are immediately eliminated, it explicitly assumes this sort of arbitrage is unrestricted and riskless.

In reality, short sellers risk massive losses if prices continue to rise before correcting (De Long et al. 1990a; Shleifer and Vishny 1997). Risk aside, short selling opportunities are often quite limited too. For example, the small float of Internet stocks prevented dissenters from shorting the 1990s bubble (Ofek and Richardson 2003), and before 2006, there were no institutional vehicles whatsoever for shorting the U.S. real estate market (Gorton 2008; Zuckerman 2009).

Accordingly, rational sitting models observe that when prices rise, skeptical investors who would otherwise short sell are often unwilling to (because of risk) or unable to (because of market conditions), and so instead they sit on the sidelines (Miller 1977; Zuckerman 2012b). This cedes the market to more optimistic investors, and bubbles can inflate unchallenged. A key implicationand one that distinguishes this perspective from collective delusion accounts - is that significant private dissent can be contemporaneous with a bubble: bubbles may be driven not by a deluded majority but by a deluded minority and silenced majority.

\section{Dissimulation through Optimal Dancing}

Sharing this expectation of widespread dissent, 
dancing models suggest that dissenters themselves may fuel a bubble by participating in - not sitting out of - the inflated market (Harrison and Kreps 1978). The logic comes originally from Keynes's ([1936] 1960) observation that in liquid markets - where investors can move in and out of positions quickly and without affecting pricespaying inflated prices may be rational if investors expect to resell at even higher prices. This strategy is the market equivalent of dissimulation in other cases of distorted valuation: investors' behavior suggests they endorse the public valuation, yet they privately dissent from it.

Investors often call such dissimulation "dancing until the music stops," and we label this set of related theories optimal dancing models because they portray dancing as an optimal strategy, where dancers profit from their speculation, exiting the market just before it crashes (e.g., Abreu and Brunnermeier 2003; Brunnermeier and Nagel 2004; De Long et al. 1990b; Temin and Voth 2004).

Crucially, though, dancing is only predicted in liquid markets. Keynes ([1936] 1960:149-54) and all modern optimal dancing models assume this necessary condition, for without a high level of liquidity, dancers run the risk of holding overpriced assets when the "music stops," and this risk outweighs the potential benefits of riding the bubble. In illiquid markets, optimal dancing models reduce to rational sitting models: investors who see that the market is in a bubble are expected to withdraw.

\section{Agenda: Testing and Developing Heterodox Theory}

This article begins by testing key implications of the heterodox approaches reviewed earlier against unique data-longitudinal interviews with private equity $(\mathrm{PE})$ participants during and after that market's mid-2000s bubble. First, we test competing predictions about investor sentiment during the PE bubble. The collective delusion perspective expects optimistic investors to predominate, whereas the institutionalist approach expects significant private dissent. This test is important because even though the institutional- ist perspective seems compelling, it has received little direct empirical validation. In fact, we find evidence of widespread investor recognition during the PE bubble that asset prices far exceeded any reasonable estimate of fundamental value, and this constitutes the first direct evidence that a bubble can persist despite significant private dissent from prevailing prices. While collective delusion about value may drive other bubbles, this test strongly suggests that bubbles do not depend on such delusion.

Second, we test institutionalist theories' common prediction about investor behavior in illiquid markets. Both rational sitting and optimal dancing models assume that investors who are sophisticated about value (who know prices are inflated) are also sophisticated in reading the market environment so as to know whether to sit or to dance - and, if they dance, that they know how to time their exit before a crash. There is no precedent, then, for our finding that in the illiquid PE market, most dissenters danced. Postbubble evidence we present indicates this was a flawed investment strategy and the reason the PE bubble inflated to such heights.

These findings lay the groundwork for a proposed theoretical revision. We argue that bubbles can inflate even when there is no collective delusion about value but, instead, when there is collective error in the investment strategies pursued. Such errors are unanticipated by existing theory, and we draw on in-depth qualitative data from the PE market to probe their nature. The data reveal how misperceptions about market liquidity and peers' strategies can make dancing seem viable even when it is not, and our analysis moves beyond institutional restrictions on voice to identify the crucial importance of institutional restrictions on market visibility as well.

Taken together, this article's findings suggest that the errors fueling bubbles may pertain less to the cognitive and behavioral challenges of ascertaining asset values and more to the sociological and institutionally driven challenge of how to interpret one's social and competitive landscape. This calls for a revision to the current behavioral finance agenda and offers a sociologically informed path forward for research on financial markets. 


\section{The Private Equity Market}

There are approximately $600 \mathrm{PE}$ firms in the United States ${ }^{2}$ Together they possess more than $\$ 1$ trillion in capital and own and control companies that employ more than 8 million American workers ${ }^{3}$ Although the few largest firms employ 100 or more investors, most have staffs of 20 or fewer.

PE firms purchase companies with the goal of reselling them at a profit. Purchases are structured as leveraged buyouts (LBOs), meaning they are financed using not only equity but also debt raised from third-party lenders (e.g., commercial or investment banks) ${ }^{4}$ The debt is secured by the assets of the acquired company. The equity is drawn from PE funds-10-year limited partnerships for which the PE firm serves as general partner and its capital providers serve as limited partners (LPs). LPs are generally large institutions, including public and corporate pension funds, university and foundation endowments, and insurance companies. When a PE firm raises a fund, LPs commit a set amount of capital. The PE firm is then responsible for investing the fund's capital. As it finds companies to purchase over the ensuing years, it calls down LPs' capital commitments to finance the purchases. Upon selling a company, the PE firm returns to LPs the original capital plus 80 percent of any profit, and retains 20 percent (called carried interest).

When evaluating prospective investments, $\mathrm{PE}$ investors engage in months-long due diligence to value a target company. Two common methods of valuation are (1) a discounted cash flow analysis, whereby a company is worth its future cash flows discounted by time and risk, and (2) the application of historical, industry-specific pur-

\footnotetext{
${ }^{2}$ Unless otherwise specified, quantitative data on the PE market concern U.S., leveraged-buyout-focused PE firms and were obtained from Pitchbook, a commercial data set focused on this market. Complete, reliable data on the PE market are notoriously difficult to obtain (Stucke 2011), but comparison of alternative data sources (based on Harris, Jenkinson, and Kaplan [2011]) suggested that Pitchbook offered at least as complete data as alternative sources. We extensively cross-checked Pitchbook's data against other sources.

3 Employment data from Private Equity Growth Council website, accessed May 7, 2012: http://www.pegcc.org/education/pe-by-the-numbers/.

4 This section draws from Kaplan and Stromberg (2009:123-30) and Tuck (2003); also industry reports, trade press, and our extensive interviews.
}

chase multiples to a company's recent operating profit, whereby a dollar of operating profit is worth the same across time and within industry. $\mathrm{PE}$ prices typically reflect multiples of earnings before interest, tax, depreciation, and amortization (EBITDA) - that is, the price, or purchase multiple, for the investment is the total capital used to purchase the company (in equity and debt) divided by the company's operating cash flow.

\section{The Mid-2000s Bubble}

The earliest PE firms were founded in the late 1960s and 1970s, and the market experienced its first bubble in the 1980s. From $\$ 1$ billion in transactions in 1980, the market soared to more than $\$ 60$ billion in transactions by 1988 , then crashed, contracting to $\$ 4$ billion by 1990 (Kaplan and Stein 1993). During the 1990s and early 2000s, the industry retrenched, then grew slowly. In the mid-2000s, an even larger bubble emerged.

Figure 1 shows the total value of all U.S. LBO deals from 1990 to 2012. Between 2005 and 2007, PE firms invested approximately $\$ 960$ billion, far more than they had invested over the entire previous decade. This run-up was characterized by an unprecedented number and size of LBOs. The median LBO deal averaged $\$ 51$ million in the 10 years prior to 2005 but grew to $\$ 59$ million in 2005 and $\$ 100$ million by the bubble's 2007 peak. Importantly, these larger deals reflected the fact that $\mathrm{PE}$ investors were paying higher prices for the same fundamentals than they had historically. For the 5 and 10 years prior to 2005 , median purchase multiples in $\mathrm{PE}$ averaged 6.6 times EBITDA, but they rose considerably during the bubble, reaching a record high of 11.4 times EBITDA in Q4 2007 and Q1 2008.

With the broader economic collapse in 2008 and 2009, the PE bubble popped and the market crashed. By 2009, the industry had returned to its early-2000s size, with only $\$ 58$ billion in LBOs, a median deal size of $\$ 40$ million, and median purchase multiples of 5.9 times EBITDA. Since the depths of the downturn, multiples and deal activity have increased somewhat, but the PE market remains far below its 2007 peak. Today there is widespread consensus among analysts and 


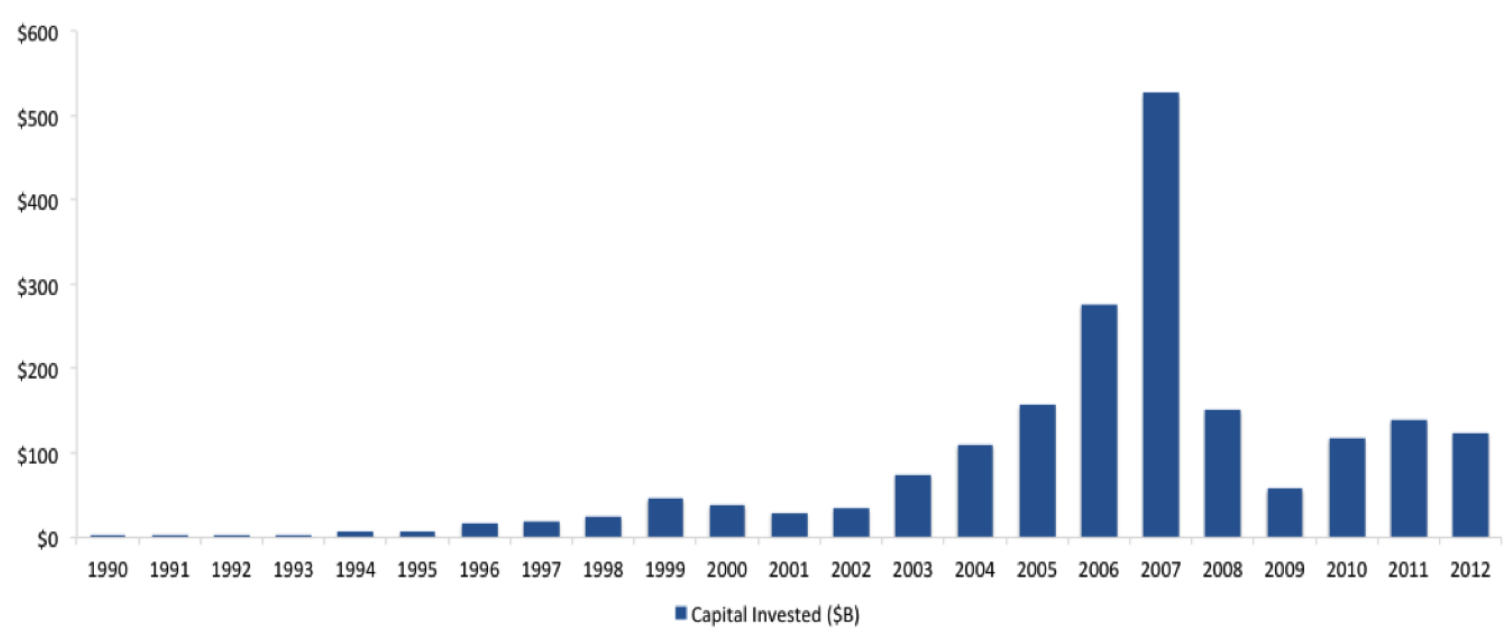

Figure 1: Aggregate LBO Deal Value by Year

market participants that this period constituted a bubble of historic proportions 5

Both to understand how this happened and to develop more robust general theory, we test existing theories of bubbles against evidence from PE. Several conditions make this an ideal setting to pursue this agenda.

\section{Conditions Suggesting Widespread Delusion}

Collective delusion is a plausible explanation for this bubble given capital market dynamics at the time. Just as the first PE bubble occurred during the 1980s' junk bond craze, this one occurred during an unprecedented surge in the credit markets. In the early 2000s, lenders began syndicating a portion of LBO debt, packaging it into collateralized loan obligations to trade in the secondary market. This shifted originating lenders' incentives and encouraged more aggressive lending practices, meaning $\mathrm{PE}$ investors could access more debt at cheaper rates than ever before (Acharya, Franks, and Servaes 2007). Concurrently, equity capital from LPs also spiked (Figure 2).

Orthodox theory would argue that price increases merely reflected these exogenous changes

\footnotetext{
5 In our interviews in 2010 and 2011, PE investors unanimously reported that the mid-2000s had been a massive bubble. Numerous industry reports and press articles discuss the unprecedented run-up in PE during those years (e.g., Pitchbook Data Inc. 2011).
}

in the cost of capital. However, the qualitative data we present later cannot be reconciled with this. For now, it is sufficient to note that such an account is inconsistent with the fact that mid2000s PE investments have performed considerably worse than those of other times: estimated average returns for $\mathrm{PE}$ funds raised during the bubble are 52 percent of the historical average 6

In fact, over the industry's history, prices have risen and returns have suffered during periods of cheap and abundant capital, suggesting bubbles are particularly likely at just these moments (Kaplan and Stein 1993; Kaplan and Schoar 2005; Axelson, Jenkinson, and Strömberg 2013; Robinson and Sensoy 2011a). The surging capital markets, combined with poor investment returns, specifically suggest PE may have experienced the sort of capital-fueled collective delusion bubble Kindelberger (1978) described - that is, perhaps PE investors unwittingly paid inflated

\footnotetext{
${ }^{6}$ At the time of this writing, current Pitchbook estimates of the median internal rate of return (IRR) for PE funds raised from 2005 to 2007 average 8.37 percent, compared to 16.07 percent for funds raised from 1980 to 2004 . This may overstate returns during the bubble because IRR calculations for those years are based, in part, on PE investors' own estimates of as-yet unrealized returns (i.e., companies bought during the bubble but not yet resold). A method of calculating PE returns that avoids this issue is the "realization multiple," that is, the capital actually returned from investments thus far divided by the total initial capital invested. For funds raised from 1994 to 2004 , the median realization multiple five years after a fund was raised averaged 0.56; for funds raised in 2005 to 2007 , it is 0.23 .
} 


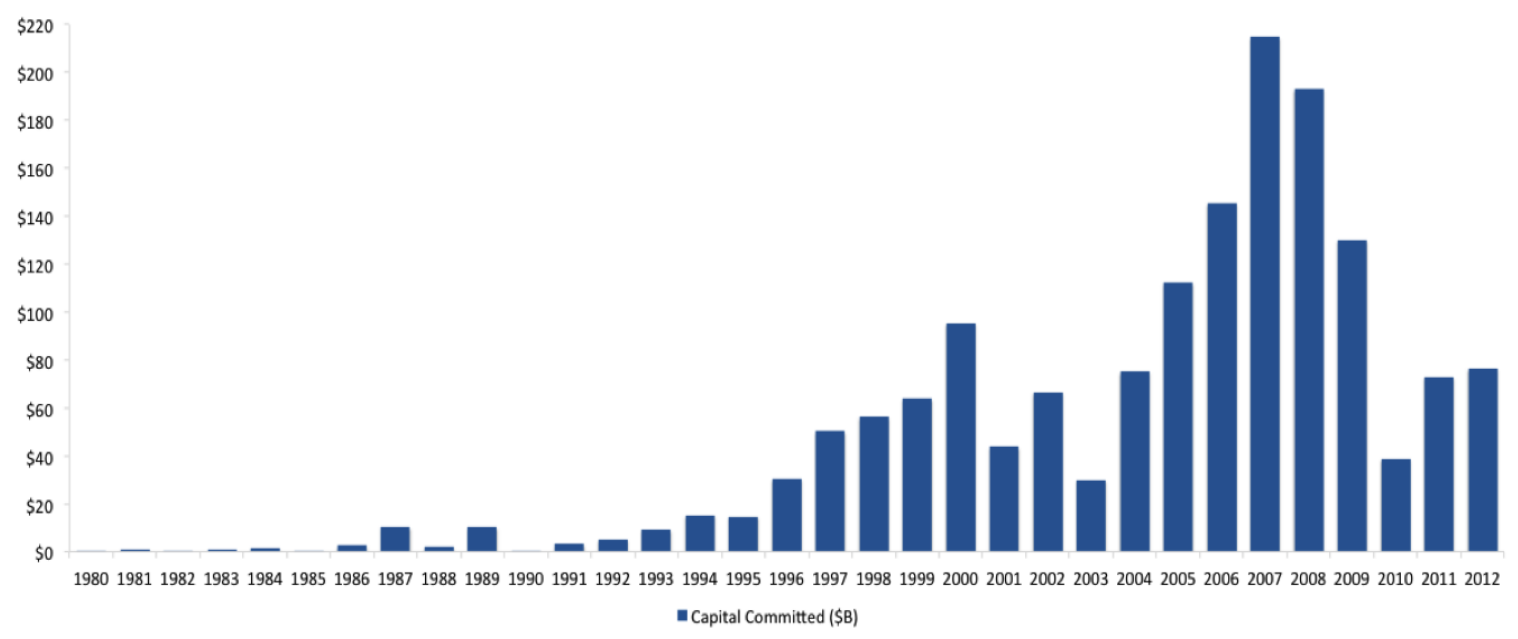

Figure 2: Limited Partner Capital Commitments to Private Equity

prices because abundant debt and equity blinded them to the actual cost of this capital.

A contemporaneous market development may have reinforced such value delusion. Historically, PE firms found LBO targets through proprietary networks. By the 2000s, however, target companies were increasingly retaining investment banks to run formalized auctions in which PE firms bid against one another. Auctions often induce participants to overpay (Thaler 1988), and because investment banks receive a percentage of the winning bid, they have an incentive to elicit the highest valuations possible regardless of fundamentals (cf. Ho 2009; Perrow 2010).

\section{Conditions Suggesting Widespread Dissent}

But could a majority of PE investors really have been so deluded about asset values? While the untrained "noise" traders driving many collective delusion stories may fall prey to behavioral biases and collective euphoria (see Akerlof and Shiller 2009; Barberis and Thaler 2005; Black 1986), PE is composed entirely of the type of investors and incentives thought to rationalize markets. Specifically, both PE firms and their LPs are sophisticated institutional investors, and the market has been explicitly structured to motivate PE investors to overcome behavioral biases and value target assets accurately (Jensen 1989).
For example, PE investors are required to co-invest alongside LPs, with at least 1 percent of any PE fund's capital coming from its own personal capital (Kaplan and Strömberg 2009). They also share in their investments' long-term profits through the 20 percent carried interest. This carried interest is itself typically contingent on factors that further motivate them to pay fair prices in pursuit of long-term returns - for example, LPs are often guaranteed a "hurdle rate," meaning PE investors receive no carried interest until LPs reach a preset return on their capital; and PE firms face "clawback" provisions allowing LPs to recall carried interest from earlier deals if later investments perform poorly (Metrick and Yasuda 2010). Given this set of incentives, institutionalist theories that explain bubbles in the absence of widespread value delusion seem like promising candidates for explaining the PE bubble.

\section{Conditions Leading to Testable Predictions}

Though compelling, institutionalist theories have received little direct empirical testing or validation, and collective delusion theories remain the most prominent account of bubbles. Two conditions, however, make PE ideal for testing institutionalist predictions. 
Short selling constraints. Testing institutionalist theories requires a market with short selling constraints, the mechanism assumed to silence even widespread dissent. PE certainly meets this condition: short selling is not just limited because of costliness or riskiness (as it is, say, in the public stock market) but rather it is outright impossible here. The assets being traded are private companies, so there are no freely traded securities to short. Moreover, the entire investment thesis is to go "long," not short, and LPs contractually bind $\mathrm{PE}$ firms to limit their investment activities to LBO-like transactions. The strict mandate is to use LP capital to purchase companies, increase their value by driving operational and strategic improvements, then resell them at a higher price. Finally, just as PE investors cannot short the market, neither can industry outsiders short the equity of privately owned companies ${ }^{7}$ Because few PE firms are publicly traded and only a portion of their capital comes from the public market, there are insufficient freely traded shares for outsiders to exercise an effective short selling strategy.

The complete absence of short selling means we can test theoretical predictions about investor sentiment during the PE bubble: institutionalist theories predict considerable silent dissent on account of the restrictions on voice, whereas collective delusion theories expect widespread delusion.

Market illiquidity. Because PE is a highly illiquid market, we can also test institutionalist predictions about investor behavior during the bubble. Entire companies - not shares on an exchange - are bought and sold in this market. PE firms hold investments for an average of six years (Kaplan and Strömberg 2009), and, when they finally do exit an investment, they must sell the company to another company or PE firm or via public offering on the stock market. These exits - like the initial LBO itself-are long, complex transactions that take months and sometimes years to complete given financial, legal, and regulatory issues. This, and the industry's long

\footnotetext{
${ }^{7}$ Some hedge funds have considered shorting the debt of PE-owned companies by buying credit default swap protection on public companies that PE firms could conceivably take private in the future (ZeroHedge 2010). This is highly indirect, and public company LBOs are a fraction of all PE investments, so such trades have minimal impact.
}

holding periods, mean investors cannot expect to sell assets readily, any time they wish.

Consequently, we should not expect PE investors to adopt a speculative orientation wherein they determine what price to pay today based on where they expect prices to move in the short term. Because they cannot liquidate holdings quickly, PE investors should be willing to pay only what they estimate the asset's intrinsic value to be. In short, given PE's illiquidity, institutionalist theories carry a clear common prediction in this market: dissenters should sit out of a bubble, not dance.

This hypothesis is compelling, but given the bubble and market conditions just described, there is reason to doubt it will be supported in PE. If $\mathrm{PE}$ investors are sophisticated and motivated to recognize when prices have risen above fundamental value, and if illiquidity makes dancing a poor strategy, then we should never see bubbles in this market. Yet PE experienced a massive bubble in the mid-2000s. This implies the market was dominated by one or two kinds of investors not easily reconciled with existing institutionalist theory and intuition: (1) those who are actually deluded into overestimating value despite their sophistication and incentives and/or (2) those who recognize that prices are inflated, yet opt to dance even though it is a poor strategy. Given this, we will not only test the predictions of collective delusion and institutionalist accounts for $\mathrm{PE}$ but also use our data on investor sentiment and strategies to move beyond these existing accounts.

\section{Methods}

This agenda necessitates capturing investors' private beliefs about value during a bubble as well as their investment strategies. Our data and methods - interviews with PE market participants $(N=82)$ in 2005 and re-interviews with those same participants in 2010 and 2011 - are uniquely suited to obtaining such evidence.

\section{The 2005 Sample: Capturing Market Sentiment in a Rising Bubble}

In 2005, the lead author conducted 43 interviews in the PE industry as part of a larger multi-year 
study on the nature and structure of PE investing. The author entered the industry with no previous awareness of - nor intent to study - a PE bubble, and no interview questions asked directly about the issue. Rather, the interviews included several open-ended questions, such as, "Is there anything else I need to know about the current PE market as I begin to study it?" and "Are there any recent trends in the industry I should be aware of?" In response to these and other questions, respondents routinely volunteered their personal opinions on valuation levels in the current market. These responses reveal market participants' beliefs about public valuations, but, crucially, without priming the idea of a bubble.

$\mathrm{PE}$ firms were randomly selected from a stratified sampling frame. First, the author compiled a comprehensive list of all PE firms. Because industry participants and observers regularly identify three distinct market segments-PE firms with small funds (several hundred million dollars or less), medium funds (several hundred million to a few billion dollars), and large funds (multibillion-dollar funds, the largest of which are called mega-funds) - and because the dozen or so largest firms represent a sizable portion of all capital in the market, it was important to stratify the list of firms by size to gain a representative sample of both perspectives and capital in the market. PE firms were then randomly selected from each stratum 8

Interviews with $\mathrm{PE}$ investors ( $N=21$ individuals; $N=18$ firms $\sqrt{9}$ were then used to build a theoretical sample of other key PE market participants, including $\operatorname{LPs}(N=6)$ that invest in numerous PE firms; major investment banks $(N=7)$ that interact with hundreds of PE firms as lenders, advisors, and auctioneers; consultants $(N=6)$ who advise PE firms on due diligence; and trade journalists $(N=3)$ who cover the entire industry. Given the industry's reputation for intense secrecy, the author initially relied on key informants and personal contacts to gain access to the randomly selected PE firms and other market participants. However, response rates proved

\footnotetext{
8 The first author also interviewed two non-randomly selected firms, where personal contacts enabled deep access and early background discussions.

${ }^{9}$ Because the author conducted interviews with several investors at each of the non-randomly selected firms, the $N$ s for firms and PE investors differ slightly.
}

high (90 percent overall) regardless of method of access.

\section{Re-interviews in 2010 and 2011: Iden- tifying Investment Strategies during a Bubble}

Following the crash, we re-interviewed the original sample, asking directly about respondents' views of the mid-2000s market (which could be compared to their earlier statements) and about their firms' specific investment strategies during those years. We later used a range of sources (industry reports, coverage of PE investments in the trade press, firms' own press releases during the bubble) to validate these self-reported investment strategies.

The second wave contains 31 re-interviews ( 72 percent re-interview rate), where we interviewed either the original respondent from 2005 or someone from the original firm. During re-interviews, respondents consistently identified several $\mathrm{PE}$ firms and LPs known for particularly good or bad performance during the bubble as well as a consulting firm that actively advised firms during the bubble. Because these institutions could offer useful analytical traction and insight into dynamics during the bubble, we added them to the sample.

In total, the 2010 and 2011 sample contains 39 interviews. A supervised research assistant conducted the majority; the lead author conducted the remainder. Table 1 presents each wave's sample structure.

\section{Test 1: 2005 Market Sentiment- Collective Delusion or Unvoic- ed Dissent?}

Our first result is straightforward. Despite factors in the capital markets and auctions that could have fed delusion, during the bubble, there was significant investor dissent from market prices, not widespread delusion that these prices reflected assets' true value.

In 2005, 16 of 18 (89 percent) PE investors in our sample reported that the market was currently in a bubble with prices inflated above 
Table 1: Qualitative Sample

\begin{tabular}{lccc}
\hline & $\begin{array}{c}2005 \\
\text { Interviews }\end{array}$ & $\begin{array}{c}2010 \\
\text { Reinterviews }\end{array}$ & $\begin{array}{c}\text { New } \\
\text { Private Equity Investors }\end{array}$ \\
$\quad$ Large $(>\$ 2 \mathrm{bn})$ & & 6 & 4 \\
$\quad$ Medium $(\$ 500 \mathrm{~m}-\$ 2 \mathrm{bn})$ & 8 & 5 & - \\
$\quad$ Small $(<\$ 500 \mathrm{~m})$ & 7 & 4 & - \\
Total & 6 & 15 & 4 \\
Limited partners & 21 & 4 & 3 \\
Investment bankers & 6 & 6 & - \\
Consultants to industry & 7 & 5 & 1 \\
Journalists & 6 & 1 & - \\
Total interviews $(N=82)$ & 3 & 31 & 8 \\
\hline
\end{tabular}

${ }^{a}$ Because of multiple interviews at several firms, $N=18$ distinct PE firms in 2005.

fundamental values 10 Reports were consistent across all market segments. A PE investor from a small firm commented, "The fundamental frustration within PE these days is the prices... If you're buying a $\$ 12$ million EBITDA business, historically you'd have to pay 6 to 7 times for it... [Now] people are willing to pay 8 to 9 times for that business. Valuations are getting crazy... We are seeing businesses we know a lot about go for stupid prices." Another small-firm investor echoed this, saying, "Today's prices are outrageous," and "It's just crazy in terms of valuations now." A mega-fund investor spoke of inflated prices, then observed, "There are a lot of dumb deals being done."

Consistent with their sense of a market bubble, such investors predicted a crash. An investor from a medium-sized firm insisted, "It's a cycle... There will be a correction." He elaborated, "PE firms are paying more for equivalent deals than they did in the past," and, consequently, "private equity will blow up. You don't have to write about it. It will happen." Another warned, "Things have been going up for a while. They

\footnotetext{
${ }^{10}$ Using Kindelberger's several definitions of a bubble, we coded respondents as dissenters (those who recognized the market's mispricing) when they used the term "bubble" to describe the current market, reported that prices were in excess of asset values (apart from changes in the financing environment), and/or said current prices were unsustainably high and going to "correct" or "crash" in the future. We used the 2010 and 2011 re-interviews to validate coding of 2005 data where possible.
}

will come down at some point too... There will be some spectacular failures."

In the full 2005 sample, 27 of 40 (68 percent) respondents reported that $\mathrm{PE}$ was in a bubble. Four of six LPs expressed skepticism about current prices. The manager of a university endowment was definitive that the market was in a bubble, drawing analogies between the current LBO market and previous bubbles elsewhere: "It's not unlike the venture [capital] world in the late-90s. People see that the venture guys were nowhere near as clever as they thought they were. Same thing is going on in the buyout world today." LPs do not directly evaluate the companies being purchased, however, and perhaps as a result, three expressed uncertainty about what these high prices meant exactly, puzzling whether prices were high because of an asset bubble or because of structural change in the industry.

Trade journalists and industry advisors working directly in the market (e.g., helping PE firms evaluate target companies) were considerably more adamant. Like most PE investors, they believed prices were inflated: two of three journalists, five of seven investment bankers, and three of six consultants in our sample reported that the market was clearly in a bubble. In 2005, one banker observed, "PE firms are overpaying now... To close a deal, they pay the extra multiple."

Like the skeptical PE investors, these advisors predicted a crash. Explaining that he was 
"suspect of the market," a consultant warned, "At some point, the market will have a correction." Another said, "We worry about what happens when the music stops." Note that trade journalists cover hundreds of firms and cultivate sources across the entire industry, and any one investment bank or consulting firm works with numerous PE firms. So, the fact that these respondents believed public valuations were inflated further validates that skepticism was prevalent across the entire market, not just our sample. Furthermore, as early as 2005 and continuing throughout the bubble, there was public speculation about the existence of a PE bubble both in the national news and trade press as well as among industry leaders at major PE conferences (e.g., Primack 2005; Dixon 2007).

The foregoing evidence constitutes the first contribution of our article. Across all categories of respondents, there was widespread dissent from prevailing public valuations in 2005. Comments that prices were "crazy," "outrageous," "stupid," and bound to "crash" cannot be reconciled with an orthodox account, which assumes prices accurately reflect value conditional on the financing environment; nor can they be explained by a collective delusion account. Instead, they represent the first, direct evidence in support of the key prediction of institutionalist accounts that markets with restricted short selling can experience bubbles despite widespread recognition of the market's mispricing.

\section{Test 2: 2005 to 2007 Dissenter Behavior-Rational Sitting or Optimal Dancing?}

But what did these dissenters (investors who believed current prices were inflated) do during the ensuing bubble years? As noted, existing institutionalist theories predict that, in markets where there are limits to arbitrage, the degree of liquidity in the market determines how dissenters behave. When markets are liquid, the optimal strategy is often to dance, buying assets at today's inflated prices to resell at higher prices prior to the market's correction (Abreu and Brunnermeier 2003). However, when markets are illiquid, as in PE, such investors should sit out until prices correct (Miller 1977).

Our data are surprising, then. While 4 of the $16 \mathrm{PE}$ investors who recognized the bubble in 2005 curtailed investment activity over the next few years, the majority - 9 of 16 - participated actively in the inflating market ${ }^{11}$ Three of the firms added in 2010 did the same. These investors purchased more companies, at a faster pace and in larger transactions than ever, paying prices they knew to be in excess of the companies' underlying values. We classify these investors as "dancers" because, as in optimal dancing models (e.g., Abreu and Brunnermeier 2003), they spoke in terms of Keynesian speculation, that is, paying high prices today with the intention of selling at even higher prices tomorrow. An investor whose firm danced during the bubble explained, "We'd project out the price that we felt we could get when we sold the business, and we felt we were basing this [the price they paid] on appropriate assumptions of sales prices."

Such behavior was not just limited to our sample. The prevalence of dancing across PE actually inspired what has become the most infamous quote of the broader financial market excesses of that time. In 2007, Chuck Prince, CEO of Citibank (a lender in many PE deals), told his employees that so long as PE investors wanted to keep dancing - as they were widely believed to be doing - then Citibank should keep providing them with debt to finance their deals: "When the music stops in terms of liquidity, things will get complicated. But as long as the music is playing, you've got to get up and dance. We're still dancing." Moreover, given the prevalence of skepticism about price levels both in our sample and in the broader PE market dialogue of the time, the sheer volume of PE investment activity in 2005 to 2007 implies considerable dancing (Figure 1).

Our 2005 interviews reveal specific examples of investor dancing at the time, offering direct evidence of this strategy. For instance, the investor who called prices "outrageous" and "crazy" explained in the same interview that his firm was

\footnotetext{
11 Given data limitations, we were unable to classify three firms in our 2005 sample as either a sitter or a dancer. Even if all three had sat out (which anecdotal evidence suggests is not the case), dancing still would have been the majority strategy in our 2005 sample.
} 
nevertheless highly focused on "closing deals" (in the homebuilding product sector, one of the most overpriced). Other investors who said prices were inflated spoke similarly about being highly "preoccupied" (in the words of one) with finding ever more investments to make in the current market.

Post-crash interviews provide further evidence of dancing and additional insight into the strategy. Dancers admitted knowingly paying high prices that were unjustified by the underlying fundamentals. An investor whose firm danced articulated the logic, "We knew we were paying prices above average for historical LBOs... We believed "we can justify paying $x$ times [EBITDA] because we'll get $x$ plus times on the way out." Across all market segments, dancers made similar admissions:

We all recognized that we were getting to a point where - let's just say to an unsustainable pace... [But] we were active... We made a lot of investments then. It's absolutely not the case that we said, "Let's stay out of market." (PE investor, mega firm)

We were fully aware we were in a bubble... We did some deals at the peak. (PE investor, medium firm)

There was a collective belief that things were at relatively high prices... The idea that people didn't know there was a bubble didn't exist. People knew these were frothy times... We definitely overpaid for the [deals] we did then. (PE investor, small firm)

A trade journalist who had identified the bubble in his 2005 interview reflected back in 2011, "PE had a bubble. Prices were rising unsustainably... I thought for the most part they [PE investors] agreed with me intellectually [that prices were inflated] but ultimately it didn't change their behavior." That it didn'tthat many investors continued to invest despite realizing the market was overpriced-leaves us with a puzzle. Although we observe that dancing occurred and fueled the PE bubble, and although this finding is consistent with the sociological and political science literature that says "dissimulation" can drive distorted valuations (Wedeen 1999), such behavior occurred in the absence of the key condition existing institutionalist theory assumes is necessary for observing it: liquidity. As one PE investor remarked, "We are not public market investors who can get in and out of the market by picking up the phone to a broker when we see things start to turn. We're dealing with sizable companies, transformative transactions that take weeks and months and sometimes years to line up." Given this, theory tells us that dancing would be suboptimal and therefore avoided. The finding of prevalent suboptimal dancing in the absence of theory to explain it constitutes our article's second contribution.

It appears that the PE bubble would not have occurred had all the investors who recognized that prices were too high sat out of the market. We learn from this that bubbles can be fueled by investors who are sophisticated in their approach to value but nonetheless err in the investment strategies they pursue. This calls for development of new theory. To do so, we must first address two key questions: Was dancing really suboptimal for PE investors? If so, why did some investors nevertheless adopt it?

\section{Was Dancing Suboptimal?}

The puzzle of PE dancing would be resolved if dancing were suboptimal only for LPs, not PE investors. Indeed, PE investors receive significant short-term economic benefits from dancing, irrespective of long-term returns. They collect transaction fees every time they buy or sell a company and annual monitoring fees from each portfolio company (Metrick and Yasuda 2010). For each fund, they also collect an annual management fee of 2 percent of the fund's committed capital. Because they cannot raise a new fund until their existing one is mostly invested, they may disregard prices and invest quickly to raise that next fund and collect more management fees.

Given recent examples of financial market malfeasance (cf. Perrow 2010), we must ask whether these short-term incentives alone can explain PE dancing during the bubble. Careful consideration suggests a more nuanced perspective, though, and the data demonstrate that despite 
its short-term benefits, dancing was suboptimal for PE investors, not just LPs.

First, these short-term incentives are always present in PE, so they cannot alone explain why investors would knowingly pay inflated prices during some periods but not others. Also, if dancers were simply exploiting LPs' capital for short-term personal gain during the bubble, why admit to us in 2005 that prices were too high? They could have obscured the malfeasance by claiming prices reflected robust economic fundamentals.

Most important, the data overwhelmingly demonstrate that dancing was simply not optimal for PE investors. In our 2010 and 2011 interviews, we asked PE investors what had been the best strategy for a PE firm to adopt during the bubble, and all but one (regardless of what strategy they had adopted) acknowledged that dancing had been wrong and that the first-best strategy was to have remained disciplined and sat out of the market by refusing to overpay for deals 12

The issue is that although there are shortterm incentives to dance, there remain powerful countervailing incentives to care about long-term investment returns. Recall that PE investors invest their own capital — not just LPs' - to purchase assets, meaning they are not simply agents. In economists' principal-agent models, having such "skin in the game" (as one respondent put it) is the key mechanism for counteracting shortterm temptations to exploit. Moreover, PE investors share in the long-term investment profits through carried interest, and such profit sharing can dwarf fee-driven compensation ${ }^{13}$ Yet dancing did not optimize such returns. Returns from investments made during the bubble have been poor relative to historical returns. As of mid-2013, PE firms still held $\$ 776$ billion worth of unsold assets, the majority of which were pur-

\footnotetext{
12 By contrast, Brunnermeier and Nagel (2004) and Temin and Voth (2004) describe dancing as the optimal strategy in the bubbles they study.

${ }^{13}$ In 2011, the three founders of the Carlyle Group, a large PE firm, each made $\$ 134$ million from their share of the firm's investment profits as well as approximately $\$ 70$ million from returns on each founder's own personal investments in the firm's funds, compared to $\$ 250,000$ in salary and $\$ 3.5$ million in bonus (i.e., the two fee-driven compensation components). That year, each also put between $\$ 97$ million and $\$ 164$ million of their own capital back into Carlyle's funds (Zuckerman and Dezember 2012).
}

chased during the bubble and were now valued either below cost or below the hurdle-rate return, meaning dancers will receive no carried interest from them.

Furthermore, investors appeared quite aware that lasting financial success in PE is achieved by raising a sequence of increasingly larger funds (not by playing a one-shot game of maximizing a single fund's fees) and that this depends upon building a track record of strong returns for LPs. They further recognized that dancing was inconsistent with that. Numerous dancers echoed one investor's sentiment that "I'd not have invested as actively and would have waited it out," preserving capital to invest after prices corrected. (Also, whereas sitters took advantage of the bubble's inflated prices to sell existing companies, dancers tended to hold theirs, believing they could sell at even higher prices later. Because transaction fees are paid when companies are bought or sold, this further suggests dancers were not just trying to maximize fees.)

In our 2010 and 2011 interviews, dancers feared a "judgment day," "shakeout," and "catastrophic consequences" for the most egregious dancers, predicting that such firms would die when LPs refused to invest in their subsequent funds. Indeed, LPs significantly reduced their commitments postbubble (Figure 2), and dancers have had considerable difficulty raising new capital relative to sitters 14

To be sure, just because dancing might jeopardize LP relationships and suboptimize long-term returns does not mean PE investors kept these factors in mind. Research on hyperbolic discounting demonstrates that actors often struggle to avoid short-term temptations even in the presence of powerful long-term incentives. However, a bedrock principle in that literature is that investment in illiquid investments is the key mechanism for disciplining actors to discount the future appropriately (Laibson 1997). Because PE is an illiquid market, PE investors should have been

\footnotetext{
14 Four PE firms in our sample raised new funds at approximately the same time in 2005. Two danced; two sat. By 2011, one dancer had given up on fund-raising and appeared to be winding down operations. After a difficult fund-raising process, the other ultimately raised a new fund that was considerably smaller than the firm's prior fund. The two sitters (who invested the majority of their 2005 funds postcrash) had both raised new, larger funds.
} 
highly attuned to the future consequences of dancing and recognized that this was a suboptimal long-term strategy, both for themselves and LPs. In fact, when we examine why respondents chose to dance, we are led directly to their beliefs about liquidity and their LPs' likely response.

\section{Misperceptions Supporting Suboptimal Dancing}

Our data suggest that two misperceptions about the market environment made dancing seem reasonable at the time and that dancers held these mistaken beliefs, whereas sitters did not. Given the nature of interview data, a causal link between these misperceptions and suboptimal dancing should be regarded as preliminary. Nevertheless, the qualitative evidence highlights their importance in investors' decision to dance.

False sense of liquidity. During the bubble, one-third of the dancers in our sample seemed to believe PE's liquidity environment had permanently changed to now support dancing. To be sure, PE was experiencing relatively high levels of liquidity, in that debt was cheap and plentiful. In 2005, sitters and dancers alike mentioned this as a major environmental factor. A mega-fund investor commented, "Capital is a commodity now," whereas one from a medium-sized firm observed, "Capital is one of the least difficult things in this space."

Sitters were appropriately skeptical of this situation, noting the debt markets were in a "crazy" and "cyclical" moment that would not last. They linked the current availability of capital to increased liquidity in PE but were clear that any increased liquidity was only as long-lived as this credit cycle. Some dancers, however, interpreted the increased availability of capital as "sustainable," reflecting the long-term "institutionalization" of PE investing. A banker who advised many dancers during the bubble captured this sentiment in 2005, saying, "This [liquidity] will never dry up... [PE] has gone from an illiquid cowboy-type environment where a small group of really bright people made money, to a very liquid environment." Respondents' postcrash comments provide further insight into such thinking. A dancer recalled internal meetings during the bubble in which he and his colleagues decided to pay prices they knew to be above fundamental value because they believed "all the now obviously false arguments" that conditions in the market had permanently changed and they would be able to sell at even higher prices later. According to an LP, dancers like this one "fundamentally believed the world had changed" and operated with "the assumption the capital markets would be there" to support dancing.

Not all dancers in our sample believed liquidity had permanently changed, however. Like sitters, another third of the dancers recognized that the capital markets were in a cyclical peak and any increased liquidity in PE was only temporary. In 2005, an investor from a mega-fund that danced said, "I feel like this will last as long as interest rates stay low, but once the cycle turns, it will be harder to get deals done... Interest rates aren't low forever."

The mistake of these dancers was to overestimate their firms' ability to navigate it successfully 15 The investor quoted earlier as saying that "PE will blow up" reported in 2005 that the success of dancing "all depends on the credit mentality," which he readily acknowledged was temporary. Yet in his 2010 interview, he recounted meetings where he and his colleagues had decided to dance for a while longer, believing there would still be time to sell their assets at higher prices. Another dancer summed up the basis for such thinking: "Everyone stayed in. . . People are going to dance as long as the music plays... Everyone was suffering from the same illusions. It was a bubble mentality. . . People's elevated view of self, 'I know what I'm doing, I can lead us through the treacherous waters."'

False sense of safety in numbers. An additional misperception supported dancing by reassuring investors that, even if dancing proved suboptimal, LPs were unlikely to punish them.

\footnotetext{
${ }^{15}$ A particular strategy that facilitated such thinking was the increased use of dividend recapitalizations ("recaps") whereby a PE firm refinances the debt of an acquired company based on a higher valuation and extracts a dividend. This strategy may have made it appear that it was easier to exit investments quickly at a profit, but recaps do not provide a level of liquidity sufficient to justify dancing (see Grant 2008). Two reasons are that (1) recaps take at least several months to complete and (2) they depend on an increase in the company's valuation from the time of acquisition, and so they depend on either value-enhancing operational improvements or further price increases, both of which take time to transpire.
} 
Specifically, dancers assumed they had "safety in numbers" (Zwiebel 1995; cf. Keynes [1936] 1960:158). In 2005, all of the respondents who went on to dance through the bubble indicated that they believed everyone else was also participating in the bubble. Most believed everyone was knowingly dancing like themselves, though some suspected there were a few "fools" in the market too, unwittingly paying high prices. Post-crash, respondents observed that a "pack mentality" had operated during the bubble. Such herding is relevant in PE because when LPs decide whether to invest in a new fund, they typically focus less on a firm's overall past performance and more on its relative performance ${ }^{16}$

By this logic, if there was a chance dancing might be successful (because one believed the liquidity environment could possibly support it), then not dancing was risky. A dancer explained, "You definitely knew you were in a boom, but you're worried about being left out." Moreover, if dancing failed, the negative consequences would be minimal and mistakes easy to justify because everyone else's returns would also be poor. Characterizing the logic he believed some dancers used, an LP said, "It was absolutely clear. Everyone knew it was insanity but you participate. If you're going to fail, do it with a lot of company... People [who danced can] say 'We all drank the KoolAid... We all made the same mistakes. Now we're getting back to business."' Consistent with this, an investor in our sample justified his own firm's dancing, saying, "We were in the same fish tank as everyone else... Most funds were hurt, right?"

Note that with a sense of safety in numbers, it then becomes reasonable to take advantage of the short-term incentives to dance (i.e., fees),

\footnotetext{
16 Two reasons for this are as follows: (1) It is unclear whether average PE returns exceed those of the public markets and thus whether LPs should allocate as much capital as they do to this risky, illiquid asset class (see Harris et al. 2011; Kaplan and Schoar 2005; Robinson and Sensoy 2011b). Nevertheless, there is general consensus that returns within $\mathrm{PE}$ vary considerably and that, at any given time, the best-performing funds outperform other asset classes. Consequently, LPs try to identify "topquartile" funds, a strategy that makes relative performance central. (2) Individual LP managers are evaluated on a relative basis themselves. Overall returns often matter less for their job security than do returns relative to "peer" institutions. Managers thus focus on investing in better $\mathrm{PE}$ funds than their peers, again making relative $\mathrm{PE}$ performance salient.
}

regardless of investments' long-term prospects. So, although we argued earlier that fee-based incentives alone were insufficient for explaining dancing, once investors mistakenly believed that they had safety in numbers and/or that the liquidity environment might support such a strategy, the temptation to exploit short-term fees likely added fuel to the inflating bubble. One sitter explained, "I guess it's the Chuck Prince phenomenon. You've gotta keep dancing. Plus they were rewarded handsomely to keep playing. The optimal strategy [in their minds] was to raise as much money as you could think of, spend it as quickly as possible and take whacking great fees... But the strategy was flawed. It all came crashing down."

Our data suggest that the reason it "all came crashing down" was because dancers' perceptions of liquidity and safety in numbers were wrong. When the market crashed, dancers had overpriced investments they could not unload and dissatisfied LPs, whereas sitters had preserved both capital and LP favor. Had dancers read their market environment correctly, they would have anticipated this outcome and sat out, and the bubble would never have occurred. Thus, although our data do not allow us to speculate about why sitters avoided these misperceptions when dancers did not, these data strongly suggest that the PE bubble was directly fueled by suboptimal dancing and that this dancing was predicated on investors having misread key environmental conditions. In the next two sections, we develop the general implications of this finding for theory.

\section{Theory Development: Mis- takes about Market Liquidity}

To appreciate this finding's novelty, contrast it with two well-known collective delusion theories. Reinhart and Rogoff (2009) attribute bubbles to the widespread belief that "this time is different" and fundamental valuations have permanently increased. But in PE, we saw investors invoke such language with regard to liquidity to justify dancing, even while recognizing that this time was not different with regard to valuations. Akerlof and Shiller (2009:152) contend that investors' animal spirits make them overconfident in both their own estimates of value and their 
estimates of others' estimates, such that they believe prices "will always go up strongly." But in $\mathrm{PE}$, we find investors who are overconfident about their ability to navigate a complicated liquidity environment. PE dancers had an accurate sense of value and even a good sense of one another's estimates of value (no one believed the market was dominated by deluded fools who had overestimated value), but they had an inaccurate sense of market liquidity. This warped their investment strategies but not their valuations (dancers knew prices were inflated).

This is a subtle but crucial difference, and it leads to a new understanding of the conditions driving bubbles. A bubble fueled by value delusion should become increasingly fragile as it inflates because even previously optimistic investors become skeptical after a point. This is why massive bubbles, which inflate well beyond any seemingly reasonable estimates of value, are so hard to understand in retrospect. By contrast, a bubble fueled by delusion about liquidity can be self-sustaining. As investors believe the market is more liquid, dancing seems more viable, and as investors dance, the market seems more liquid. Given this dynamic, collective liquidity delusion may explain the extent and duration of many major financial market bubbles better than value delusion.

The notion of a liquidity delusion also moves beyond existing institutionalist theories. Both optimal dancing and rational sitting models assume one-to-one correspondence between skill in estimating asset values and skill in reading the market environment: that is, investors who spot the market's mispricing are assumed to read the liquidity environment correctly and so know whether it is better to sit or dance - and if they dance, they are assumed to know where prices are going and when they will crash. To appreciate what is distinct in our findings, consider a memo that leaked throughout the PE industry and trade press in 2007.

William Conway, the co-founder of one of the largest PE firms, the Carlyle Group, wrote a memo to his staff in January 2007. Like many of our respondents, he directly linked the "enormous availability of cheap debt" to liquidity and dancing in PE: "There is so much liquidity in the world financial system that lenders (even 'our' lenders) are making very risky credit decisions.
This debt has enabled us to do transactions that were previously unimaginable... and has resulted in (generally) higher exit multiples than entry multiples." He acknowledged, "This liquidity environment cannot go on forever. I know that the longer it lasts, the greater the pressures will be on all of us to take advantage of this liquidity. And I know that the longer it lasts, the worse it will be when it ends... But I do not know when it will end." Nevertheless, he wrote (in all capital letters) that he expected it "WILL CONTINUE FOR AT LEAST THE NEXT 12-24 MONTHS. FRANKLY, I SEE NO CATALYST THAT WILL LEAD TO A QUICK, LARGE, OR DRAMATIC CHANGE IN GLOBAL LIQUIDITY."

This memo is telling for two reasons. First, existing institutional theories suggest that if a prominent player publicly broadcasts that prices are inflated, such broadcast will act as a "coordinating event," causing the bubble to burst (Abreu and Brunnermeier 2003). The logic is akin to a child announcing that the emperor has no clothes (Centola et al. 2005): once it becomes common knowledge that prices are inflated, dancers close out their positions because they expect others to do so. Yet Conway's memo was clear that market prices had become inflated, and the PE bubble did not burst immediately in response. This seems to reflect the fact that PE dancing was fueled by erroneous beliefs about liquidity, and on this score, the memo did not clarify matters (and, in fact, liquidity evaporated much sooner than Conway forecasted). Investors already widely believed the emperor was naked (there was a bubble), and they assumed their peers were equally aware; but given the erroneously perceived environmental conditions of high debt-fueled liquidity into the foreseeable future, they reasoned it was best to dissimulate (dance). Had Conway's memo challenged this perception, it might have occasioned a crash.

In short, it was not enough for investors to appreciate, as Conway and many dancers in our sample did, that the market's debt-fueled liquidity could not support dancing indefinitely; they also had to recognize that they would be unable to time their exits before that liquidity evaporated. This distinction between debt-fueled liquidity and the more transactional sense of it constitutes the second lesson we can draw from Conway's memo and our foregoing findings: mistakes about liq- 
uidity may be especially likely given the complex nature of the phenomenon. The ability to move in and out of positions in a market is a function of both (1) conditions in the broader capital markets and (2) the nature of the transactions themselves. A large supply of cheap capital can make transactional liquidity seem higher for a period of time, but visibility into when - and how quickly - the capital markets will turn is notoriously difficult, for it depends on highly complex, systemic activity outside one's own market. And when the capital markets do turn, the nature of the market's transactions ultimately determines whether dancers can exit in time.

\section{Theory Development: Mistakes about Peer Behavior}

A second theoretical implication of this study pertains to the crucial role of market visibility in bubbles. Recall that although one-fourth of our sample curtailed investment activity, the dancers believed everyone was participating in the bubble. When we examine why they developed this false sense of safety in numbers, we uncover a constellation of institutional factors that obscured others' sitting. We do not identify one single factor as directly responsible because sitting's invisibility is actually overdetermined in PE. Rather, our analysis suggests how a range of institutional conditions can impact market visibility and thus where scholars and policy makers might direct their attention when seeking to study and manage future bubbles.

Start with short selling constraints. A previously unappreciated implication of short selling constraints is that they not only silence dissenting voices but also obscure sitters' strategy. The PE case reveals that in the absence of countervailing mechanisms to support visibility, investors who stay in the market see only those investors who are also actively participating, not those who have departed, and this can skew their perception of peers' investment strategies, thus motivating a decision to dance.

Of course, sitters' behavior could still become visible via social networks. After all, awareness of peer strategies often spreads through formal and informal ties, like those observed among some traders (e.g., Preda 2012; Simon et al. 2012). However, the presence of networks has not prevented past bubbles, perhaps because social networks do not necessarily promote trust. (If an investor hears that some peers have sat out, how can the investor know this is not just a strategic decoy?)

In fact, and in contrast to what others have found in public markets, our interview data suggest that PE investors rarely communicate with one another directly about current investment activities. This is unsurprising as PE firms historically sought proprietary deals of which their competitors were unaware and now participate in blind auctions. Participants sign legal documents forbidding communication with the other PE firms in the auction, and they can see neither which firms those are nor their bids. Such restrictions aim to prevent PE firms from colluding to suppress prices, but they also obscure visibility into one anothers' strategies.

The dominance of auctions also means that $\mathrm{PE}$ investors gain market information (e.g., overall investment activity and pricing levels) only if they participate. This is how they gain access to company financials and can compare their own estimates of value to ultimate sale prices. Consequently, PE firms rarely ever withdraw completely from the market. One sitter explained, "No PE firm will tell you they stepped out of the market. You can't afford to. You still want to see deals, stay in the flow." In a sense, sitters thus engage in their own form of dissimulation. To remain informed of market conditions (and in hopes of winning a deal at a fair price if ever possible), sitters continued to participate in auctions during the bubble, conducting due diligence and submitting bids. But in contrast to dancers, they only bid their estimate of a company's underlying value, meaning they consistently lost and effectively sat out.

To the extent sitters were visible, then, they looked like dancers. Cultural dynamics in PE likely encouraged this reading. Although sitting out can prevent future loss of capital, it does not generate returns and so garners little attention, whereas "doing deals" carries the prospect of returns and is more culturally salient as reflected in industry vernacular (Turco 2010). Accordingly, the trade press covers deal activity (who is doing what deals), not its absence. 
Such dynamics may also help explain why LPs apparently failed to transmit information about sitting to dancers. While some sitters explained their strategy to LPs, most did not advertise their inactivity. (As discussed, LPs in our sample were unsure how to interpret the heated market, and they do not make money from PE sitting.) Nevertheless, PE investors did receive market information from some third parties - their investment bankers, lenders, and consultants. But these actors are paid per transaction, profiting from high levels of market activity, and by 2010 and 2011, some PE investors speculated that such advisors may have hyped deal activity and downplayed the extent of sitting to serve their own interests.

Taken together, the foregoing observations suggest that even when investors are directly or indirectly connected to one another, they may not have good visibility into peer strategies. To the contrary, the institutional context may obscure peer behavior, not reveal it. While existing institutionalist theories have overlooked this, recent work in the sociology of distorted valuation offers some relevant insights. Consider two recent contributions. In Strang and Macy (2001), managers over-adopt faddish business practices because they lack visibility into peer firms' behavior, relying instead on business press and consultants who overstate the overall adoption and efficacy of those practices. Similarly, in Centola et al.'s (2005) analysis of unpopular norms, actors who cannot see the full distribution of peer behavior (e.g., conformity, deviance, enforcement) are more likely to engage in false adoption and enforcement.

Although neither model speaks directly to the PE bubble, each is consistent with the idea that institutional features of markets can obscure the full range of peer strategies, and that this can lead actors to pursue suboptimal strategies that drive distorted valuations, just as we saw in PE. Our evidence also points to a key but hidden assumption in these models: actors are often unaware of, and thus fail to adjust for, institutional limits on visibility (see also Zuckerman 2012:228). More generally, if past institutionalist theories of bubbles imply that short selling constraints act like restrictions on freedom of expression in other cases of distorted valuation, our case demonstrates that a market's institutional features can also act like restrictions on freedom of assembly, preventing investors from coming together and observing one another's strategies directly, and that this can fuel a bubble.

\section{Conclusion}

We began by noting that collective delusion and institutionalist accounts make distinct predictions about the extent of dissent during bubbles. Our first finding lent strong support to an institutionalist explanation of the PE bubble. Therefore we should no longer presume that collective delusion on valuation is necessary to drive bubbles. Nevertheless, our second finding of suboptimal dancing and our analysis of the false assumptions underlying it suggest that the PE bubble was indeed fueled by a form of collective blunder, just one unanticipated by existing theory. Specifically, we documented a case of collective error on investment strategy and identified the mistakes investors made in reading their environment that led to that.

This has potentially far-reaching consequences for financial market research. All heterodox theory seems to assume that the key errors investors make pertain to valuation and that conditional on arriving at a given valuation, investors follow the appropriate investment strategy. This assumption is core to behavioral finance in its examination of the cognitive and behavioral traps that lead actors to misestimate asset values (see Barberis and Thaler 2005; Hirshleifer 2001). It also appears in institutionalist models of sitting and dancing, where investors who are smart about valuation are assumed to be smart about reading the market environment and selecting the optimal investment strategy for it. On its face, this assumption seems reasonable, because investors who are motivated and able to accurately assess an asset's fundamental value would seem motivated and able to determine an appropriate investment strategy relative to that asset. Cases of successful dancing suggest it is sometimes an accurate assumption (Brunnermeier and Nagel 2004; Temin and Voth 2004). Yet our results suggest that we can better understand financial market dynamics if we relax this assumption.

A key implication of our study is that the cognitive challenge of accurately valuing tangible 
assets may pale in comparison to the more sociological challenge of understanding a market's complex social and competitive dynamics to select the appropriate investment strategy. Although particular aspects of this challenge are salient in $\mathrm{PE}$, the more general challenge of navigating an environment that is collectively constructed by market participants - and thus seemingly more or less liquid - is generic. And if the highly motivated, sophisticated PE investors collectively failed at this challenge, it is quite likely that other bubbles are driven by similar failures.

Finally, by highlighting the role of collective delusion about liquidity and institutional limits on visibility, our study has important policy implications. First, we find that dancing can fuel a bubble even when there is widespread recognition of the bubble and even when the sustainability of liquidity is publicly questioned. Perhaps the only measures to defuse such a bubble, then, are limiting the supply - or raising the cost - of capital. Accordingly, policy makers should be vigilant when the cost of capital is so low that it may promote liquidity delusion even when there is no value delusion.

A second lesson is that, just like other cases of distorted valuation, bubbles should be seen less as the product of intractable behavioral tendencies and more as the product of institutional failure and thus amenable to institutional solutions. When the environment is highly complex and presents participants with a biased picture of one another's strategic behavior, there is a significant likelihood of collective error in the strategies that are adopted. This results in what we have seen in the PE bubble - an episode of distorted valuation, whereby the "smart money" was too smart by half - that is, with limited visibility into the market, they applied the wrong investment strategy despite knowing the right valuation. Future research should examine how institutional conditions that create transparency may promote more accurate interpretations of the complex social and collective environment that is the market.

\section{References}

Abreu, Dilip and Markus Brunnermeier. 2003. "Bubbles and Crashes." Econometrica
71:173-204. http://dx.doi.org/10.1111/ 1468-0262.00393

Acharya, Viral, Julian Franks, and Henri Servaes. 2007. "Private Equity: Boom and Bust?" Journal of Applied Corporate Finance 19:1-10. http://dx.doi.org/10.1111/j 1745-6622.2007.00158.x

Akerlof, George and Robert Shiller. 2009. Animal Spirits: How Human Psychology Drives the Economy, and Why It Matters for Global Capitalism. Princeton, NJ: Princeton University Press.

Axelson, Ulf, Tim Jenkinson, and Per Strömberg. 2013. "Borrow Cheap, Buy High? The Determinants of Leverage and Pricing in Buyouts." Journal of Finance 68:2223-67. http://dx.doi.org/10.1111/jofi.12082

Barberis, Nicholas and Richard Thaler. 2005. "A Survey of Behavioral Finance." Pp. 1-78 in Advances in Behavioral Finance, vol. 2, edited by Richard Thaler. Princeton, NJ:Princeton University Press.

Black, Fischer. 1986. "Noise." Journal of Finance 41:529-43. http://dx.doi.org/10 1111/j.1540-6261.1986.tb04513.x

Brunnermeier, Markus and Stefan Nagel. 2004. "Hedge Funds and the Technology Bubble." Journal of Finance 59:2013-40. http://dx.doi.org/10.1111/ j.1540-6261.2004.00690.x

Centola, Damon, Robb Willer, and Michael Macy. 2005. "The Emperor's Dilemma: A Computational Model of Self-Enforcing Norms." American Journal of Sociology 110:1009-40. http://dx.doi.org/10.1086/427321

De Long, J. Bradford, Andrei Shleifer, Lawrence Summers, and Robert Waldmann. 1990a. "Noise Trader Risk in Financial Markets." Journal of Political Economy 98:703-38. http://dx.doi.org/10.1086/261703

De Long, J. Bradford, Andrei Shleifer, Lawrence Summers, and Robert Waldmann. 1990b. "Positive Feedback Investment Strategies and Destabilizing Rational Speculation." Journal of Finance 45:379-95. http://dx.doi.org/ $10.2307 / 2328662$

Dixon, Hugo. 2007. "The Greed Fear Imbalance." Wall Street Journal, January 29. 
Fligstein, Neil and Adam Goldstein. 2010. "The Anatomy of the Mortgage Securitization Crisis." Pp. 29-70 in Markets on Trial: The Economic Sociology of the U.S. Financial Crisis: Part A, edited by Michael Lounsbury and Paul Hirsch. Research in the Sociology of Organizations 30. Bingley, UK: Emerald.

Garber, Peter. 2000. Famous First Bubbles: The Fundamentals of Early Manias. Cambridge, MA: MIT Press.

Gorton, Gary. 2008. "The Subprime Panic." Working Paper, Yale International Center for Finance.

Grant, James. 2008. "Subprime Companies." Pp. 339-43 in $M r$. Market Miscalculates: The Bubble Years and Beyond. Mount Jackson, VA: Axios Press.

Harris, Robert, Tim Jenkinson, and Steven Kaplan. 2011. "Private Equity Performance: What Do We Know?" Working Paper, University of Chicago Booth School of Business.

Harrison, J. Michael and David Kreps. 1978. "Speculative Investor Behavior in a Stock Market with Heterogeneous Expectations." Quarterly Journal of Economics 92:323-36. http://dx.doi.org/10.2307/1884166

Hirschman, Albert. 1970. Exit, Voice, and Loyalty: Responses to Decline in Firms, Organizations and States. Cambridge, MA: Harvard University Press.

Hirshleifer, David. 2001. "Investor Psychology and Asset Pricing." Journal of Finance 56:1533-97. http://dx.doi.org/10.1111/ 0022-1082.00379

Ho, Karen. 2009. Liquidated: An Ethnography of Wall Street. Durham, NC: Duke University Press. http://dx.doi.org/10.1215/ 9780822391371

Jensen, Michael. 1989. "Eclipse of the Public Corporation." Harvard Business Review 67:6174.

Kaplan, Steven and Antoinette Schoar. 2005. "Private Equity Performance: Returns, Persistence, and Capital Flows." Journal of Finance 60:1791-1823. http://dx.doi.org/ 10.1111/j.1540-6261.2005.00780.x

Kaplan, Steven and Jeremy Stein. 1993. "The Evolution of Buyout Pricing and Financial
Structure in the 1980s." Quarterly Journal of Finance 108:313-57. http://dx.doi.org/ $10.2307 / 2118334$

Kaplan, Steven and Per Strömberg. 2009. "Leveraged Buyouts and Private Equity." Journal of Economic Perspectives 23:121-46. http: //dx.doi.org/10.1257/jep.23.1.121

Keynes, John Maynard. (1936) 1960. The General Theory of Employment, Interest, and Money. New York: St. Martin's Press.

Kindelberger, Charles and Robert Aliber. (1978) 2005. Manias, Panics, and Crashes: A History of Financial Crises. Hoboken, NJ: John Wiley. http://dx.doi.org/10.1057/ 9780230628045

Laibson, David. 1997. "Golden Eggs and Hyperbolic Discounting." Quarterly Journal of Economics 112:443-78. http://dx.doi.org/10 1162/003355397555253

Lamont, Owen A. and Richard H. Thaler. 2003. "Can the Market Add and Subtract? Mispricing in Tech Stock Carve-outs." Journal of Political Economy 111:227-68. http: //dx.doi.org/10.1086/367683

MacKenzie, Donald. 2011. "The Credit Crisis as a Problem in the Sociology of Knowledge." American Journal of Sociology 116(6):17781841. http://dx.doi.org/10.1086/659639

Metrick, Andrew and Ayako Yasuda. 2010. "The Economics of Private Equity Funds." Review of Financial Studies 23:2303-41. http://dx doi.org/10.1093/rfs/hhq020

Miller, Edward. 1977. "Uncertainty, and Divergence of Opinion." Journal of Finance 32:1151-68. http://dx.doi.org/10.1111/ j.1540-6261.1977.tb03317.x

Minsky, Hyman. 1975. John Maynard Keynes. New York: Columbia University Press.

Minsky, Hyman. 1992. "The Financial Instability Hypothesis." Working Paper 74, Jerome Levy Economics Institute of Bard College.

Ofek, Eli and Matthew Richardson. 2003. "Dotcom Mania: The Rise and Fall of Internet Stock Prices." Journal of Finance 58:1113-37. http://dx.doi.org/10.1111/ 1540-6261.00560

Perrow, Charles. 2010. "The Meltdown Was Not an Accident." Pp. 309-30 in Markets on Trial: 
The Economic Sociology of the U.S. Financial Crisis: Part A, edited by Michael Lounsbury and Paul Hirsch. Research in the Sociology of Organizations 30. Bingley, UK: Emerald.

Pitchbook Data Inc. 2011. The Pitchbook Decade Report: Vol. II: Investments 2001-2010. Seattle, WA: Pitchbook Data.

Pozner, Jo-Ellen, Mary Kate Stimmler, and Paul Hirsch. 2010. "Terminal Isomorphism and the Self-Destructive Potential of Success: Lessons from Sub-Prime Mortgage Origination and Securitization." Pp. 183-216 in Markets on Trial: The Economic Sociology of the U.S. Financial Crisis: Part A, edited by Michael Lounsbury and Paul Hirsch. Research in the Sociology of Organizations 30. Bingley, UK: Emerald.

Preda, Alex. 2012. "Tags, Transaction Types and Communication in Online Anonymous Markets." Socio-Economic Review 11:31-56. http://dx.doi.org/10.1093/ser/mws011

Primack, Dan. 2005. "CalPERS Exec Warns of Private Equity Bubble." Venture Capital Journal, March 1.

Rashes, Michael S. 2001. "Massively Confused Investors Making Conspicuously Ignorant Choices (MCI-MCIC)." Journal of $\mathrm{Fi}$ nance 56:1911-27. http://dx.doi.org/10 1111/0022-1082.00394

Reinhart, Carmen and Kenneth Rogoff. 2009. This Time Is Different: Eight Centuries of Financial Folly. Princeton, NJ: Princeton University Press.

Robinson, David and Berk Sensoy. 2011a. "Cyclicality, Performance Measurement, and Cash Flow Liquidity in Private Equity." Working paper, Ohio State University.

Robinson, David and Berk Sensoy. 2011b. "Private Equity in the 21st Century: Cash Flows, Performance, and Contract Terms from 19842010." Working paper, Duke University.

Shleifer, Andrei and Robert Vishny. 1997. "The Limits to Arbitrage." Journal of Finance 52:35-55. http://dx.doi.org/10.1111/j 1540-6261.1997.tb03807.x

Simon, Jan, Yuval Millo, Neil Kellard, and Ofer Engel. 2012. "Dangerous Connections: Hedge Funds, Brokers and the Construction of a Mar- ket Crisis." Working Paper, London School of Economics.

Strang, David and Michael Macy. 2001. "In Search of Excellence: Fads, Success Stories, and Adaptive Emulation." American Journal of Sociology 107:147-82. http://dx.doi org/10.1086/323039

Stucke, Rudiger. 2011. "Updating History." Working Paper, Oxford University.

Temin, Peter and Hans-Joachim Voth. 2004. "Riding the South Sea Bubble." American Economic Review 94:1654-68. http://dx doi.org/10.1257/0002828043052268

Thaler, Richard. 1988. "Anomalies: The Winner's Curse." Journal of Economic Perspectives 2:191-202. http://dx.doi.org/10 1257/jep.2.1.191

Tuck School of Business. 2003. "Note on Leveraged Buyouts." Case 5-0004, Center for Private Equity and Entrepreneurship, Tuck School of Business at Dartmouth College.

Turco, Catherine. 2010. "Cultural Foundations of Tokenism: Evidence from the Leveraged Buyout Industry." American Sociological Review 75:894-913. http://dx.doi.org/10.1177/ 0003122410388491

Wedeen, Lisa. 1999. Ambiguities of Domination: Politics, Rhetoric, and Symbols in Contemporary Syria. Chicago: University of Chicago Press.

ZeroHedge. 2010. "How to Capitalize on the Upcoming Irrationally Exuberant LBO Bubble." Zero Hedge, March 20. http://www.zerohedge. com/article/how-capitalize-upcomingirrationally-exuberant-lbo-bubble.

Zuckerman, Ezra. 2012a. "A Sociological Approach to Market Efficiency." Pp. 223-49 in Oxford Handbook on the Sociology of Finance, edited by Karin Knorr-Cetina and Alex Preda. New York: Oxford University Press.

Zuckerman, Ezra. 2012b. "Construction, Concentration, and (Dis)Continuities in Social Valuations." Annual Review of Sociology 38:223-45. http://dx.doi.org/10.1146/ annurev-soc-070210-075241

Zuckerman, Ezra and Hayagreeva Rao. 2004. "Shrewd, Crude, or Simply Deluded? Comovement and the Internet Stock Phenomenon." 
Industrial and Corporate Change 13:171212. http://dx.doi.org/10.1093/icc/13 1.171

Zuckerman, Gregory. 2009. The Greatest Trade Ever: The Behind-the-Scenes Story of How John Paulson Defied Wall Street and Made Financial History. New York: Broadway Books.

Zuckerman, Gregory and Ryan Dezember. 2012. "Appetite for (Creative?) Destruction." Wall Street Journal, January 13.

Zwiebel, Jeffrey. 1995. "Corporate Conservatism and Relative Compensation." Journal of Political Economy 103:1-25. http: //dx.doi.org/10.1086/261973

Acknowledgements: Laurel Grassin-Drake provided valuable research assistance on this project. Earlier versions of this article benefited from the generous advice of Sarah HalpernMeekin, Kate Kellogg, and Ray Reagans and from the feedback of audiences at the HBS Entrepreneurial Management Seminar, the International Network of Analytical Sociologists' 2012 Conference at Columbia University, the Brandeis University Sociology Department, and MIT Sloan's Organization Studies Group. Direct correspondence to Catherine J. Turco, Sloan School of Management, Massachusetts Institute of Technology.

Catherine J. Turco: Sloan School of Management, Massachusetts Institute of Technology.

E-mail: cturco@mit.edu.

Ezra W. Zuckerman: Sloan School of Management, Massachusetts Institute of Technology.

E-mail: ewzucker@mit.edu. 